\title{
STUDENTS' LANGUAGE LEARNING STYLES: AN ETHNOGRAPHIC CASE STUDY AT UIN WALISONGO SEMARANG
}

\author{
Muhammad Nafi Annury \\ UIN Walisongo Semarang \\ nafiannury@gmail.com
}

\begin{abstract}
This research is aimed at knowing kinds of learning preferences the students intend most and types of learners'characteristics appear in ELT classrooms. This research was conducted through qualitative approach. The data are collected questionnaires, documentation, and observation. The result of this study shows that students of ELT program at UIN Walisongo Semarang tend to study by various kinds of learning. Among students of $2 \mathrm{~A}, 11.2 \%$ are visual students, $16.02 \%$ are audio-lingual, $5 \%$ are kinesthetic and the rest $14.11 \%$ are others, would use multimedia which available in the classroom. Whereas, students of $2 \mathrm{~B}$ show that $13 \%$ of them are visual learners, $11 \%$ are audiolingual learners, $6.72 \%$ are kinesthetics and the rest $13,72 \%$ are others. Students of $2 \mathrm{C}, 12 \%$ of them are visual learners, $11.17 \%$ are audiolingual, $7.25 \%$ are kinesthetics and the rest $14 \%$ are others.
\end{abstract}

Keywords: learning-styles,unity of science 


\section{Introduction}

In this modern era, the implementation of learning style approach in the classrooms is crucial. Lots of researchers have regularly identified aspects of learning and created new terms and instruments, which are no doubt an indication of the complexity of the learning process. As others build on and modify that "field" becomes wider and less focused, the results of the research are more confusing for teachers and students to apply. A valid and reliable information of learning styles in classroom makes students' profiles more clearly defined. Students might be stereotyped or pigeonhole themselves thus limitting their learning potential and success.

Teacher must approach learning styles cautiously, which are not a panacea. Becoming aware of learning and teaching styles prepare teachers for the better multicultural classroom. In addition, raising students' awareness to the advantages and the disadvantages of learning styles makes students not only more prepared for learning but also more analytic about learning styles.

Another problem faced by teachers is the difficulty of being all things to all students. For example, if we expect teachers to be sensitive about the students' learning styles. To solve this problem is preparing students to be administered and involved in any situation of teaching-learning process.

\section{Backround Literature}

\section{Learning}

Manser (1995: 320) says Learning is relatively permanent change in a behavioral tendency and as the result of reinforced practice. Learning is an activity to gain knowledge or skill. Therefore, learning is the process by which skills, knowledge, attitude, and behavior are formed and developed. It takes place as a result of education, training and socialization. Brown (2000) Breaks down the components of the definition of learning, we can extract as we did with language, domains of research and inquiry. They are as follows:
a. Learning is acquisition or "getting"
b. Learning is retention of information or skills
c. Retention implies storage system, memory and cognitive or- 
Students' Language Learning Styles ...

ganization

d. Learning involves active, concious focus on, asome and acting upon events outside or inside and organism

e. Learning is relatively permanent but subjective to forget

f. Learning involves some form of practice, perhaps reinforced practice.

g. Learning is a change in behavior

These concepts can also give away to a number of subfields within the discipline of psychology: actuation proces, perception, memory, system recall, concious, learning style and strategies, reinforcement and the role of practice (Brown, 2000: 11).

Learning is the process of teaching students by using the principle of education and theoretical learning is the determinant main the education (Syaiful, 2003:61). Hamalik (2007:77) argues that learning is a system that is a whole consisting of the components interact between one to another and with the whole itself to achieve the goal of teaching that has been set in advance. As for these components include the purpose of education and teaching, learners and students, educational personnel, especially teachers, lesson planning, teaching strategies, instructional media, and teaching evaluations. According to Dimyati and Mudjiono (2006:17) learning is teacher's instructional program, in design to make students learn actively; who insists on provision of learning. Whereas Coney (in Sagala, 2006: 61) says that learning as a process whereby environ someone purposefully managed to allow he participate in attitude in special or certain conditions produces response to a particular situation.

It can be concluded that learning is a process undertaken by teacher who has been programmed in order membelajarkan students to achieve the purpose of learning as specified in accordance with instructions curriculum prevailing. In the process of learning requiring teachers to create a conducive atmosphere of learning that students can learn in an active manner. 


\section{Types of learning}

All individuals learn- whether they do it consciously or unconsciously. It is a fundamental requirement of existence. Individual learning is defined as the capacity to build knowledge through individual reflection about external stimuli and sources, and through the personal re-elaboration of individual knowledge and experience in light of interaction with others and the environment.

a. Individual learning

All individuals learn- whether they do it consciously or unconsciously. It is a fundamental requirement of existence. Individual learning is defined as the capacity to build knowledge through individual reflection about external stimuli and sources, and through the personal re-elaboration of individual knowledge and experience in light of interaction with others and the environment. Here, we refer individual learning in the context of organization. In other words it implies that How an individual learns in an organization and how is it important in an organization. Hence, Howard Gardner explains that every human has his own multiple intelligences such as: verbal/linguistics; logical mathematical; visual/spatial; interpersonal; musical/ rhythmic; bodily/ kinesthetic and naturalistic. Afterall, there are also a number of intelligences that called by spiritual quotion and accentual one. Every singel human well of course has those intelligences above, but what should to know that they have varieties of intelligences anyway. Besides, there are some main types of learning styles. They are as follows: auditory, visual and kinesthetic. In order to get good result of learning, most people apply these three combination of these learning styles.

b. According to Vester this content - as, by the way, any material "independent of its degree of difficulty" (p.49) - can be learned in different ways suitable for the different learning types of learners. Vester differentiates between 4 types:

- Learning type 1: auditive learning ("by listening and speaking ${ }^{6}$ ),

- Learning type 2: visual learning ("through the eyes, by watching"), 
Students' Language Learning Styles ...

- Learning type 3: haptic learning ("by touching and feeling"),

- Learning type 4: learning through the intellect.

\section{Theory of Learning Cycle}

People may learn from their experience. It needs to go through the learning cycle. David Kolb states that for true learning to take place, we need to have an experience, reflect upon the experience, make sense of it and finally apply our theories to our livesby planning what we would do next time we were in the same or similar situation.

\section{Theory of Competence}

This theory states that learning is a four stage process, which involves the journey from unconscious incompetence to unconscious competence.

a. Unconscious incompetence: The individual neither understands nor knows how to do something, nor recognizes the deficit, nor has a desire to address it.

b. Conscious incompetence: Though the individual does not understand or know how to do something, he or she does recognize the deficit, without yet addressing it.

c. Unconscious incompetence: The individual understands or knows how to do something. However, demonstrating the skill or knowledge requires a great deal of consciousness or concentration.

d. Conscious incompetence: The individual has had so much practice with a skill that it becomes "second nature" and can be performed easily (often without concentrating too deeply). He or she may or may not be able to teach it to others, depending upon how and when it was learned.

Based on the explanation above, we might say that there are some competences involved within the children's mind. Here are some aspects that should be known by teachers or parents in building the good competences as well. There is no stupid students, ac- 
tually, if we may maximize their potencial insight of the students' characteristics. Teachers may come along with students to create certain type of learning in the classroom, so that it will raise students' motivation facing the subjects.

\section{Learning styles}

Learning styles in education are the systematic differences in individuals' natural or habitual pattern of acquiring and processing information in learning situations. A core concept is that individuals differ in how they learn. The idea of individualized learning styles originated in the 1970s, and has greatly influenced education.

People of the use of learning styles in education recommend that teachers assess the learning styles of their students and adapt their classroom methods to best fit each student's learning style. Although there is ample evidence that individuals express preferences for how they prefer to receive information, few studies have found any validity in using learning styles in education. Critics say there is no evidence that identifying an individual student's learning style produces better outcomes. There is evidence of empirical and pedagogical problems related to the use of learning tasks to "correspond to differences in a one-to-one fashion." $\mid$ Well-designed studies contradict the widespread "meshing hypothesis", that a student will learn best if taught in a method deemed appropriate for the student's learning style.

According to the explanation above the writer wants to introduce the model of learning styles which derives from Neil D. Fleming's VARK model (sometimes VAK) which expanded upon earlier Neuro-linguistic programming (VARK) model. They are as follows:
a. Visual learners
b. Auditory learners
c. Reading- writing preference learners
d. Kinesthetic learners or tactile learners.

Fleming claimed that visual learners have a preference for seeing (think in pictures; visual aids that represent ideas using methods other than words, such as graphs, charts, diagrams, symbols, 
etc.). Auditory learners best learn through listening (lectures, discussions, tapes, etc.). Tactile/kinesthetic learners prefer to learn via experience-moving, touching, and doing (active exploration of the world; science projects; experiments, etc.). Its use in instruction allows teachers to prepare classes that address each of these areas. Students can also use the model to identify their preferred learning style and maximize their educational experience by focusing on what benefits them the most.

It is important to understand that these are not learning styles but rather the method in which the stimuli is taken in. One might expect that learning music would suit a learner who has some strong Aural preferences, but music can be very effectively learned by those who employ read/write, visual, or kinesthetic strategies, or all-four.

\section{Methods}

In research this approach executed is through qualitative approach. It means data are not collected in the form of numbers, but data were from manuscript interview notes field, documents personal, notes memo and other formal documents. So the purpose of this qualitative study was to describe the empirical reality behind the phenomenon in depth, detailed and thoroughly. Therefore, the use of qualitative approach in this research is to match between the empirical reality with the theory that applies to the use their descriptive method. According to Keirl and Moleong Miller in the definition of qualitative research is a particular tradition in social science is fundamentally dependent on observation in humans on its own, and connect with the people in their local language and its terms.

Qualitative research method is used to examine the condition of natural objects, where researchers are as a key instrument, data collection techniques are combined, the data analysis is inductive qualitative research results, and more emphasis on generalization of meaning. Therefore, qualitative research assumes that all knowledge is relative, that there is a subjective element to all knowledge and research, and that holistic, ungeneralisable studies are justifiable (an ungeneralisable study is one in which the insights and outcomes generated by research cannot be applied to contexts or situations 
beyond those in which the data were collected). (Nunan, D. 1992). In metaphorical terms qualitative research is "soft".

Descriptive research studies problems in society, as well as the procedures applicable in the community as well as particular situations, including about relationships, activities, attitudes, outlooks, as well as the processes that are being conducted and the influences of a phenomenon.

Based on the characteristics of this research and the attention focused to study, then the theoretical mentioned by Meltzer, Petras, and Reynold is phenomenology (Bogdan and Biklen, 1992: 31) that all qualitative researchers in certain ways reflect the phenomenological perspective. It means that all researchers will try to understand hard about certain condition and what kind of interaction which suitable for people to become as well as possible. Particularly in research to understand what is the meaning of events and interactions for people can be in certain situations.

The data were collected through direct observation, questionnaire, and documentation. Meanwhile, the subjects of this study are students of the second semester of 2014/2015 at English Education Department of UIN Walisongo. The total number of students are 120 .

\section{Findings}

\section{The Description of Learning Characteristics of the 2A Stu- dents}

Based on the result of the questionnaires which is given the students, we can see some following responses stated below:

First, here there was $11.20 \%$ students of A class TBI FITK UIN Walisongo Semarang categorized into visual leearners. It was seen from the tendency of the how the studying English by such a following points: 1) Mind sometimes strays during verbal activities. 2) Observes rather than talks or acts. 3) They are well-organized in approach to tasks. 4) They like to read alot. 5) They usually a good speller. 6) They always memorize by seeing graphics and pictures. 7) They do not too distractible. 8) Sometimes, find verbal ins inuctions difficulties. 9) They have good handwriting. 10) They easily remem- 
ber someone faces. 11) Students usually use advanced planning. 12) They like doodling alot. 13) Sometimes they quiet by nature. 14) Students are so meticulous and neat in appearances. 15) Therefore, they always notice in every details.

Second, on the other hand, there was a $16.02 \%$ student at this classroom identified as audilingual or auditory ones. This characteristics can be taken from this following explanations: 1) Students talk to self aloud by the way. 2) They are enjoy talking to each other. 3) They also tend to easily distracted by their surounding actually. This condition makes them inconfinient for studying, otherwise they have good achievement however. 4) Most of them have more difficulties with written directions. They have to pay extra consentration to follow the direction which is given from teachers in the classroom. 5) This kind of students tends to enjoy listening materials which is read by teachers. Teachers should pay more efforts to make their students understand about their subjects. 6) Memorizing by steps in a sequence in the classroom a lot.7) Students really do like music, and they enjoy it much. 8) It sounds funny but it truly happens that students of auditory learners often whisper to themselves while reading. 9) They are easily in memorizing someone's faces. 10) Just like point number 3 that students are easily distracted by some surrounding noise. 12) Again, students in this type really like humming or singing. 13) Last but not least, they do like listening activities.

Third,the next characteristic is kinesthetic. It can be seen that in this classroom; students who have kinesthetic one approximately almost 5\%. The kinesthetic characteristic can be seen from this following indicators: 1) Students like much about physical rewards. They like to do something rather than others activities. 2) We may see that students seem to be busy with their motion most of the time. 3) They also like to touch people when talking to others. Their gesture is very dominant in doing communication all the time. 4) Students often make taping pencils on the tables or foot while studying. 5) Therefore, we often meet students who enjoy their activities inside or outside in the classroom then. 6) Reading is not their priority for them, because reading makes them inconvenient much. They 
do not to move around so that they can feel enjoyable a lot. 7) When teacher asks them to spell or read aloud; it will make them nervous just because sometime they have bad pronunciations. Besides, they are bad speller. 8) Therefore, students like to solve their problems by physically working amongst others. 9) They also have a strong motivation so that they will try something new and 10) they have favorite activities outside of the classroom. 11) If they have problems, it can be seen from their emotion which is expressed through physical means. 12) They always use hands while talking to others. 13) They wear dresses for comfort. Last but not least 14) Students like handling objects

Fourth, the rest of the students who have different characteristic are $14.11 \%$ in the classroom. There are a huge number of students who have various kinds of learning characteristics. It can explain that the students who have different characteristic might be classified based on reading-writing preference (Kolb, 1984: 34). There are some preferences which are introduced by Kolb.

\begin{tabular}{|c|c|c|c|}
\hline $\begin{array}{l}\text { Accommoda- } \\
\text { tors: Concrete } \\
\text { Experience }+ \\
\text { Active Experi- } \\
\text { ment }\end{array}$ & $\begin{array}{l}\text { Converged: } \\
\text { Abstract Con- } \\
\text { ceptualiza- } \\
\text { tion + Active } \\
\text { Experiment }\end{array}$ & $\begin{array}{l}\text { Diverger: } \\
\text { Concrete } \\
\text { Experience } \\
\text { + Reflective } \\
\text { Observation }\end{array}$ & $\begin{array}{l}\text { Assimilator: } \\
\text { Abstract Con- } \\
\text { ceptualization }+ \\
\text { Reflective Obser- } \\
\text { vation }\end{array}$ \\
\hline $\begin{array}{l}\text { "Hands-on" } \\
\text { and Concrete }\end{array}$ & $\begin{array}{l}\text { "Hands-on" } \\
\text { and Concrete }\end{array}$ & $\begin{array}{l}\text { Real life ex- } \\
\text { perience and } \\
\text { discussion }\end{array}$ & $\begin{array}{l}\text { Theories and } \\
\text { facts }\end{array}$ \\
\hline Wants to do & Analogies & Imaginative & $\begin{array}{l}\text { Theoretical mod- } \\
\text { els and oraphs }\end{array}$ \\
\hline $\begin{array}{l}\text { Discover } \\
\text { method }\end{array}$ & $\begin{array}{l}\text { Specific prob- } \\
\text { lems }\end{array}$ & $\begin{array}{l}\text { More than one } \\
\text { possible solu- } \\
\text { tion }\end{array}$ & nale rather than \\
\hline $\begin{array}{l}\text { Sets objec- } \\
\text { tives/ sched- } \\
\text { ules }\end{array}$ & $\begin{array}{l}\text { Test hypoth- } \\
\text { esis }\end{array}$ & $\begin{array}{l}\text { Brainstorm- } \\
\text { ing and group } \\
\text { work }\end{array}$ & Lecturers \\
\hline $\begin{array}{l}\text { Asks questions } \\
\text { fearlessly }\end{array}$ & Best answer & $\begin{array}{l}\text { Observe rather } \\
\text { than to do }\end{array}$ & Numbers \\
\hline $\begin{array}{l}\text { Challenges } \\
\text { theories }\end{array}$ & Works alone & Alternatives & $\begin{array}{l}\text { Defines prob- } \\
\text { lems }\end{array}$ \\
\hline Adaptable & $\begin{array}{l}\text { Problems } \\
\text { solving }\end{array}$ & & Logical formals \\
\hline
\end{tabular}




\section{The Description of Learning Characteristics of the 2B Students}

Based on the result of the questionnaires which are given to the students, we can see the following responses:

First, there were $13 \%$ students of $\mathrm{B}$ class are categorized into visual leearners. Second,there was 11\% student at this classroom identified as audilingual or auditory ones. Third,the next characteristic is kinesthetic one. It can be seen that in this classroom; students who have kinesthetic one approximately almost $6.72 \%$. Fourth, the rest of the students who have different characteristic are $13.72 \%$.

\section{The Description of Learning Characteristics of the 2C Stu- dents}

There were 35 students who answered the the questionnaire. The rest of the students did not attend in the classroom when the questionnaire had taken unfortunately. Students gave check (V) according to the appropriate selection which were given on the check list above. Each student has to responsible with his/her choice as well. It is important because the researcher wanted to know the real condition of students' learning styles characteristics in the classroom. There are fourty five items which should be chosen by the students in ditermining their learning styles characteristics based on the following table above.

Based on the result of the questionnaires which are given to the students, we can see some following responses stated below:

First, $12 \%$ students of $\mathrm{C}$ class are categorized into visual learners. Second, $11,17 \%$ student are identified as audilingual or auditory. Third, students who have kinesthetic style are approximately almost $7,25 \%$. Fourth, the rest of the students who have different characteristic are 14\%. Having known those characteristics the writer would recommendthat multimedia would help students to understand every subject easily. Otherwise, students would have many problems in teaching-learning process unfortunately. The use of multimedia takes the important roles in every teaching-learning process, because it would make the process of teaching-learning more interesting, enjoyable, effective and efficient. 


\section{Conclusion}

Thelecturers do not need to spend much time giving explanation orally.Multimedia will present pictures, graphs or sounds that make the subjects look like the real one. Students only need pay their attention to the slide and listening to the lecturers' explanation to get better understanding. In the last session lecturers give some instruction to make some assessments.

It is also important for the education institution to take account of the teaching-learning facilities as well. Otherwise, teachers will face any problems in delivering their subjects.

\section{Suggestion}

In the future we hope that there will be another research which may be developed from the previous research. By this, There are lots of researchers have regularly identified aspects of learning and created new terms and instruments, which is no doubt an indication of the complexity of the learning process. As others build on and modify that "field" becomes wider and less focused; consequently, the result of the research are more confusing for teachers and students to apply. There can be optimistic in hopping a valid and reliable learning styles in classroom, makes students "profiles" are more clearly defined. It is probably, that students profiles become coommonplace, the risk would be high. Students might be stereotyped, or students might pigeonhole themselves, thus limitting their learning potential and success.

Thatstudents develop their capabilities in the classroom is so much expected. Parents, especially, always keep their attention toward children academic improvements. Most of them do not realize that every children have theirown learning characteristics. The questions of how and where they may improve their learning capabilities still become parents' curiosity. Implementing of multiple intelligences is one the method to solve educational problems in the future. 


\section{REFERENCES}

Bogdan, Robert. C \& Biklen. 1990. Riset Kualitatif Untuk Pendidikan: Pengantar Teori dan Metode. Jakarta: Ditjen Dikti Depdikbud.

Chatib, Munif . 2012. Sekolahnya Manusia. Pustaka Pelajar

Djamarah, Syaiful Bahri. 2000. Guru dan Anak Didik dalam Interaksi Edukatif. Jakarta Rieneka Putra.

Elliot Stephen N., Educational Psychology, Amerika: Von Hoffman Press, 2000.

Gardner, H. 1983. Frames of mind: The theory of multiple intelligences. New York: Basic Books.

Gardner, H. 1998. A multiplicity of intelligences. Scientific American Presents: Exploring Intelligence, 9 (4), 19-23.

Gardner, H. 1999. Intelligence reframed: Multiple intelligences for the 21st century. New York: Basic Books.

Gardner, H. 2006. Multiple intelligences: New horizons. New York: Basic Books.

Key learning community. 2007. Retrieved April 16, 2008, from http:// www.616.ips.k12.in.us.

Kolb, David. 2006. The Importance of Learning Styles. Green Wood Press. 
Hamalik, Omar. 2007. Dasar-dasar Pokok Pendidikan. Bandung. PT Erisco

Kartini Kartono. 1989. Pengantar Metodologi Research Social. Bandung : Aluni.

Martin, H Manser. 1995. Oxford Learners Pocket Dictionary. Oxford: Oxford University Pers

Moleong, Lexy, 1991. Metode Penelitian Kualitatif .Bandung: Remaja Rosda Karya.

Mulyasa. 2010. Metodologi Penelitian Kualitatif. Yogyakarta.

Nazir. 2003. Metode Penelitian. Jakarta: PT. Ghalia Indonesia.

Tuckman, Bruce W. 1978. Conducting Educational Research. New York: Basic Books 